\title{
Late to the Game? Capital Flows to the Western Balkans
}

\section{Zsóka Kóczán}

International Monetary Fund, Washington, DC, USA zkoczan@imf.org
CroEconSur

Vol. 20

No. 2

December 2018

pp. 33-67

Received: May 15, 2018

Accepted: October 23, 2018

Research Article

doi:10.15179/ces.20.2.2

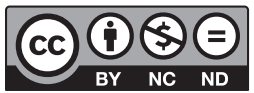

\section{Abstract}

The boom and bust in capital flows to the New Member States (NMS) has received considerable attention, relatively little has, however, been written about capital flows to the Western Balkans, often perceived to be 'late arrivals' to large capital flows. We find that while financial integration took off later in the Western Balkans, it has increased rapidly, despite lower capital account openness. Capital inflows are (perhaps surprisingly) diverse in terms of source countries, but broadly similar in terms of drivers and composition, though with equity shares higher than they were in the NMS at comparable levels of development.

Keywords: capital flows, foreign direct investment, Western Balkans

JEL classification: F32, F41, O57, P27 


\section{Introduction ${ }^{12}$}

The past 25 years have witnessed dramatic changes in Eastern Europe. In the late 1990s and especially the early 2000s private capital inflows to the later New Member States (NMS) increased rapidly, driven by overall capital scarcity, relatively high initial levels of human capital, and the institutional anchor of potential EU membership. While these flows increased investment and employment, and provided financing for external current account imbalances, they also increased the countries' exposure to external shocks. The global financial crisis triggered a sharp drop in capital flows, raising important questions about the vulnerability of these economies - a slowdown in capital flows could have important spillover effects on the real economy, through financial channels (on account of cross-border bank flows) or employment (particularly related to foreign direct investment) —and about the ways policy can respond most effectively ${ }^{3}$.

The boom and bust in capital flows to the NMS has received a considerable amount of attention; foreign direct investment (FDI) and bank flows to the region, and countries' participation in regional supply chains have been welldocumented. Relatively little has, however, been written about capital flows to the Western Balkans. While sharing many of the characteristics of the NMS, transition in the Western Balkans has lagged behind that in the NMS, as reflected for instance in a still relatively less developed private sector, and correspondingly high unemployment rates. The Western Balkan economies are also often perceived to be less open 'late arrivals' to large capital flows.

1 A version of this paper was previously published as a working paper: Kóczán, Zsóka. (2017). Late to the game? Capital flows to the Western Balkans. IMF Working Paper No. $17 / 92$.

2 Throughout the paper the term Western Balkans refers to Albania, Bosnia and Herzegovina, Croatia, FYR Macedonia, Montenegro, and Serbia. Central and Eastern Europe includes the Czech Republic, Hungary, Poland, Slovakia, and Slovenia. Southeastern Europe includes Bulgaria and Romania. Central and Southeastern Europe refers to these seven countries jointly. New Member States (NMS) also includes Estonia, Latvia, and Lithuania. Emerging Europe includes the NMS and the Western Balkan economies. In compressing the experience of 16 countries over 15 years, the paper inevitably focuses on broad common themes, and cannot do justice to the nuance and diversity of individual country experiences. While Croatia joined the EU in 2013 and differences in the economic and institutional contexts between the EU and non-EU countries are likely to affect trade and financial flows, it is treated here as part of the Western Balkans country group as most of the analysis focuses on the period predating its accession.

3 See also for example, Cardarelli, Elekdag, and Kose (2010) and Hegerty (2009) on the macroeconomic implications of large capital inflows. 
This paper aims to examine how capital flows to the Western Balkans compare with flows to the NMS, in terms of levels as well as dynamics. Have the Western Balkans indeed opened up later and does this still translate into lower capital inflows when compared to the NMS? How do they measure up to the NMS at comparable levels of development? Do capital flows in the Western Balkans respond to the same factors as in the NMS? Have the Western Balkans missed out on rapid capital inflows as a driver of growth, or has their 'late arrival' resulted in a less pronounced boom-bust cycle?

The paper is structured as follows: section two provides a brief overview of the large literature on capital flows, focusing on the Western Balkans and the NMS. Section three discusses the data used, and section four provides descriptive evidence on the evolution of stocks as well as flows. Section five outlines the empirical methodology used to examine the drivers of capital flows and presents the results, while section six brings the conclusion and policy recommendations.

\section{Literature Review}

An extensive empirical literature has sought to explain the determinants of crossborder capital flows, focusing on gross inflows and/or net flows. GDP growth rate differentials and global risk aversion have typically emerged as the most robust statistically significant determinants of aggregate capital flows to emerging market economies (see Ahmed \& Zlate, 2013; Nier, Sedik, \& Mondino 2014; Koepke, 2015; and IMF, 2016a).

Numerous studies have examined the experience of Central and Eastern Europe during the early years of transition. Early work by Lankes, Stern, Blumenthal, and Weigl (1999) and Claessens, Oks, and Polastri (2000) noted a dramatic increase in private capital flows (especially FDI and portfolio equity investment) in the first decade of transition. Árvai (2005) and von Hagen and Siedschlag (2010) examined the effects of capital account liberalization. Lane and Milesi-Ferretti (2006) analyzed the evolution of net external asset positions and highlighted 
the large accumulation of net external liabilities, with FDI flows especially prominent in financing external current account imbalances.

The boom-bust cycle of the NMS has also received a considerable amount of attention. Bakker and Gulde (2010) argued that the credit boom-bust cycle was to a large extent the result of factors external to the region, as rapid credit growth followed due to high liquidity in global markets and the attractiveness of 'new Europe' for capital flows, but that policies and policy failures (in particular, overly expansionary macroeconomic settings and excessively optimistic views on prudential risks) also played a critical role. Jevčák, Setzer, and Suardi (2010) also found that external factors (such as the euro area macroeconomic and financial conditions and risk aversion) played a role in explaining foreign capital flows, but that the responsiveness of capital flows to global factors varied across recipient countries. Globan (2015) argued that the macroeconomic factors in the euro zone were becoming increasingly dominant determinants, especially after EU accession, and that the rising importance of push factors was also connected with the higher volatility of capital inflows, making host countries more prone to sudden stop episodes. The role of EU accession was emphasized earlier by Buch and Piazolo (2001). Brixiova, Vartia, and Wörgötter (2010) noted that in Estonia an open capital account, the prospect for EU entry, and the currency board facilitated massive capital inflows. Meyer (1995), Keren, and Ofer (2002), and Jimborean and Kelber (2017) focused on FDI flows and pointed to the roles of proximity to Western Europe, institutional factors, and external, as well as domestic determinants, respectively. Mitra (2011) looked at data on the sectoral composition of inflows to the NMS and found that capital flows into real estate had a greater impact on swings in GDP than on other sectors, irrespective of a country's exchange rate or fiscal policy.

Few papers focused explicitly on capital flows to the Western Balkans. A recent book by Murgasova, Ilahi, Miniane, Scott, and Vladikova-Hollar (2015) reviewed macroeconomic developments in the Western Balkans over the past 15 years, including external balances and capital inflows, and highlighted increasing 
(mainly FDI) inflows in the boom years, and their relative stability in the postcrisis period - in contrast with the experience of the NMS, which saw declining and eventually negative capital inflows. Ganić (2013) examined the increased integration of the Western Balkans in global economic flows, highlighted the importance of geographic factors, and the corresponding prominent role of the EU as a source of (especially FDI) flows to the region. Gabrisch (2015) used Granger causality tests to examine linkages between changes in the real exchange rate and net capital inflows to the Western Balkans and found that changes in net capital flows preceded changes in relative unit labor costs. Estrin and Uvalic $(2014,2016)$ focused on FDI flows and noted that even when the size of their economies, the distance from the source economies, and the institutional quality and prospects of EU membership are considered, Western Balkan countries receive less FDI than other transition countries. Kersan-Škabić and Tijanić (2014) examined the impact of FDI on regional development in Croatia and found that investment (both domestic and FDI), labor productivity, and exports have a positive and significant influence on regional development. Kovtun, Meyer Cirkel, Murgasova, Smith, and Tambunlertchai (2014) looked at the employment impact of capital inflows and highlighted that while in the NMS the infusion of capital from abroad (especially via greenfield FDI) played a key role in developing new businesses or even new sectors and provided a chance for workers dismissed from the declining areas to be reabsorbed by new economic activities, delayed transition and low FDI put the Western Balkans at a disadvantage in diversifying away from traditional sectors.

The aim of this paper is to build on this literature, while providing value added by integrating the analysis of flows as well as stock positions, relying on a more comparative analysis relative to the NMS, and extending the analysis to the roles of common and country-specific factors, in the boom years as well as in the aftermath. To the best of the author's knowledge, this is the first paper to examine these questions for the Western Balkans in this framework. 
The empirical framework used in the following sections is motivated by international investors' optimal portfolio allocation decisions. Cross-border capital flows reflect decisions by residents and non-residents to allocate investments across countries. Investments in a particular country are more desirable the higher the risk-adjusted returns, relative to the returns from investing in other countries. Expected returns from investing in a particular country can hence be related to factors such as growth and interest rate differentials (and factors that may influence these-for instance, changes in countries' terms of trades, which could be significant during the time period examined here), the risk appetite of investors, the quality of domestic policymaking and institutions (affecting country's risk as well as expected returns), and barriers to investment, such as capital controls. Capital flows to a given country are thus expected to be higher where risk-adjusted returns are higher (for instance, due to higher relative growth, higher relative interest rates, favorable terms of trade, or better institutions and policies) and lower if global risk aversion or country risk are higher, and if capital controls are more stringent.

\section{Data}

The following analysis relies on quarterly data on capital flows from the Financial Flows Analytics database and annual data on stocks from the External Wealth of Nations database. The sample covers the Western Balkans, as well as the NMS and the EU-15 for comparison, over the period 1995-2014 .

In all of the following, capital inflows are defined as net acquisition of domestic assets by non-residents; capital outflows are defined as net acquisition of foreign assets by residents, excluding reserve assets; net capital inflows are defined as the difference between capital inflows and outflows. Net capital inflows and changes in reserve assets together constitute the financial account balance, as defined in the IMF's Balance of Payments Manual. Total gross inflows and outflows exclude

4 Some of the analysis focuses on the EU-14, excluding Luxembourg as a financial center. 
derivatives flows; equity flows refer to the sum of FDI and portfolio equity; debt flows refer to the sum of portfolio debt and other flows. All flows are measured as shares of GDP.

In the panel regressions, country-specific forecasted growth and interest rate differentials are measured as the difference between the country's own rate and a simple average of EU-14 (or NMS or Western Balkan) rates. Real interest rates are based on policy rates, deflated using one-year ahead World Economic Outlook inflation forecasts. Institutional quality is measured using the World Governance Indicators (WGI) rule of law measure. While this is used as one possible proxy for institutional quality due to its better cross-country coverage than other (more disaggregated) indicators, results are robust to using alternative measures (which are often highly correlated). Capital account openness is measured using the Chinn and Ito (2006) index. A large IMF-supported adjustment program is defined as growing IMF borrowing above 100 percent of the respective country quota and is included here both as an indicator of the country already experiencing distress, and possibly a factor lowering country risk. Fixed and floating exchange rates are defined using the IMF's Annual Report on Exchange Arrangements and Exchange Restrictions (AREAER) classification. Regional growth differentials are defined using simple averages of Western Balkans (or NMS) and EU-14 growth rates. Global risk aversion is measured using the logarithm of the CBOE S\&P 100 Volatility Index (VXO). The change in the oil price refers to the year-on-year change in the West Texas Intermediate (WTI) oil price.

\section{Descriptives}

While, as noted earlier, the evolution of the external positions of the NMS has been well-documented, relatively little has been written on the Western Balkans, especially since the crisis. Before turning to an analysis of the determinants of capital flows, this section thus aims to provide an overview of the evolution of the flows, and correspondingly, external stock positions of the Western Balkan 
economies over the past two decades, and examine where the region is now, particularly in comparison to the NMS and the EU-15.

As noted in the existing literature, capital flows to the Western Balkans arrived somewhat later than to the NMS. Their experience during the boom years of 2003-2007, however, followed (a perhaps surprisingly) similar trend (Figure 1, panel 1) $)^{5}$. Capital inflows as a share of GDP increased from about 10 percent in 2003 to around 35 percent at their peak in 2007 in both the Western Balkans and in Central, Eastern, and Southeastern Europe (the Baltics saw an increase from about 15 percent to 40 percent of GDP). This does, however, mask heterogeneity within the region: Montenegro constitutes an outlier in much of the following analysis, characterized by much larger (particularly real estate-related) flows than the other economies in the region (capital inflows there peaked at 84 percent of GDP in 2007).

Figure 1: Capital Inflows and Outflows in the Western Balkans and the NMS, \% of GDP

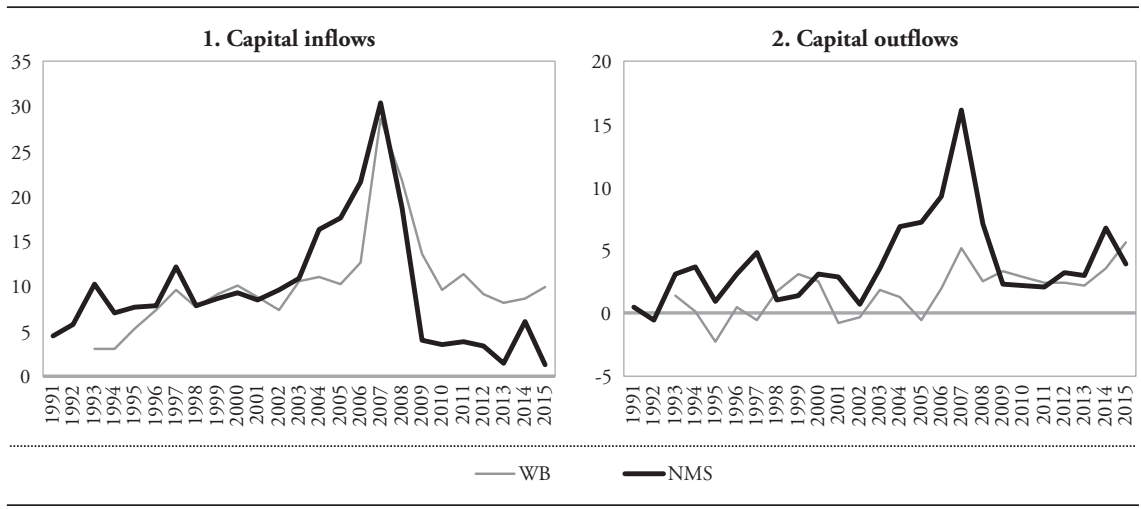

Source: IMF Financial Flow Analytics database.

In some cases, geographical proximity and relatively cheap labor allowed these economies to become part of an integrated cross-border production chain

5 Regional averages in Figures 1-4 are computed as simple averages of capital flows to GDP across countries. Alternatively, they could have been computed as total flows as a share of total GDP. Given the very different sizes of Western Balkan economies, both carry problems: in the first case due to the disproportionate influence of Montenegro and Kosovo, while in the second case, Croatia and Serbia would dominate the charts. As the aim here is to reflect diversity across the region, countries are given equal weight. 
(see Murgasova et al., 2015). Geographic proximity seems to be an important driver of capital flows, with West European countries being the dominant external investors in the region. Most of the portfolio investment in the Western Balkans comes from the EU-15: 60-80 percent of total portfolio investment in the Western Balkans on average, similar to the ratio for the NMS (Appendix Figure 1, panel 1). Investment from the NMS remained below 5 percent even at its peak, being directed mostly to Croatia and more recently to Montenegro. Intra-regional investment remains negligible in comparison; even within the NMS it is mostly below 5 percent, with the exceptions of Latvia (with a peak at 10 percent) and Slovakia (with a peak at over 20 percent).

Within the EU-15 the picture is perhaps surprisingly diverse (Appendix Figure 1, panel 2). Austria, Germany, and Greece play prominent roles, to a lesser extent so do France, the UK, and Italy (mostly in Albania). While bilateral data on FDI is less reliable and patchier than for portfolio flows, it broadly confirms the pattern, with Austria, Germany, and Greece playing important roles, a larger role for the NMS and (as expected) a smaller role for financial centers (Luxembourg and the UK). The pattern is similar to that observed in the NMS, where Austria and Germany are especially significant; Denmark, Finland, and Sweden are prominent investors in the Baltics and Greece is important for Bulgaria and Romania ${ }^{6}$.

Gross capital outflows, on the other hand, played only a relatively minor role in the Western Balkans (Figure 1, panel 2) and were mostly characterized by volatility, with no clear patterns over time. This was qualitatively similar to the experience of Southeastern Europe, whereas Central and Eastern Europe and the Baltics saw increasing inflows in the boom accompanied by increasing outflows-in line with the positive correlation between inflows and outflows documented by Broner, Didier, Erce, and Schmuckler (2013).

6 Bilateral investment flows also correlate strongly with migrant destinations, except for Luxembourg, as a financial center, and Ireland and the UK, whose labor markets have remained relatively closed to the Western Balkans. This could be driven by a combination of geographic (linguistic) factors or historical ties driving both investment and migration patterns, or by investment by migrants and their children in their home countries. 
Booming capital inflows translated into the accumulation of large net external liabilities, in the Western Balkans as in the NMS (Figure 2). Both net equity and net debt positions worsened, and while in the 1990s equity shares in the Western Balkans were even smaller than in the NMS, by 2007 both net equity and net debt positions were comparable to those of the NMS. Financial integration (measured as the sum of external assets and liabilities as a share of GDP) increased, though it remains below the levels observed in the NMS (Appendix Figure 2).

Capital inflows to the Western Balkans consisted primarily of FDI and bank loans (Figure 3, panels 1-4)7. This composition of inflows is, again, consistent with patterns observed in the NMS ${ }^{8}$. As in the NMS, capital outflows from the Western Balkans were also predominantly FDI and bank flows, though with a smaller share of the latter, and (as noted above) lower overall outflows (Figure 3, panels 5-8).

Figure 2: Net Equity and Debt Positions, \% of GDP

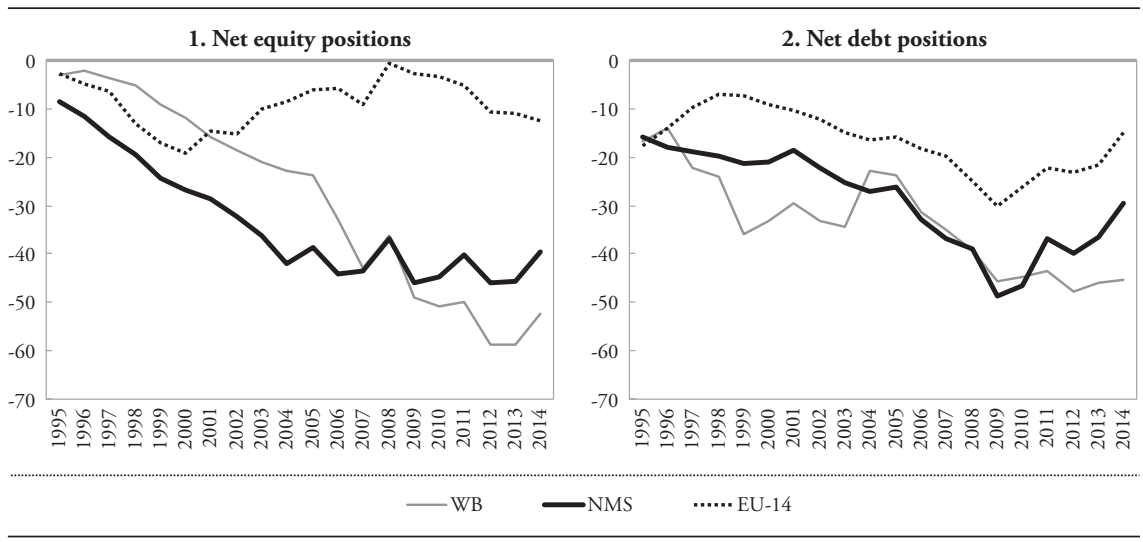

Note: Net equity (debt) positions refer to assets minus equity (debt) liabilities.

Source: External Wealth of Nations database.

7 For the 1995-2014 period as a whole, FDI accounted for around half of all inflows, while 'other investment flows' (mostly bank lending) constituted a further 40 percent. During the 2006-2008 period, bank inflows gained importance as foreign bank networks became more prevalent in the Western Balkans.

8 Portfolio inflows were small or even negative: portfolio equity (debt) flows averaged around 0.2 (1) percent of GDP in the Western Balkans; portfolio debt flows were only slightly higher in the NMS. 
Figure 3: Capital Inflows and Outflows in the Western Balkans and the NMS, by Type of Flow, \% of GDP
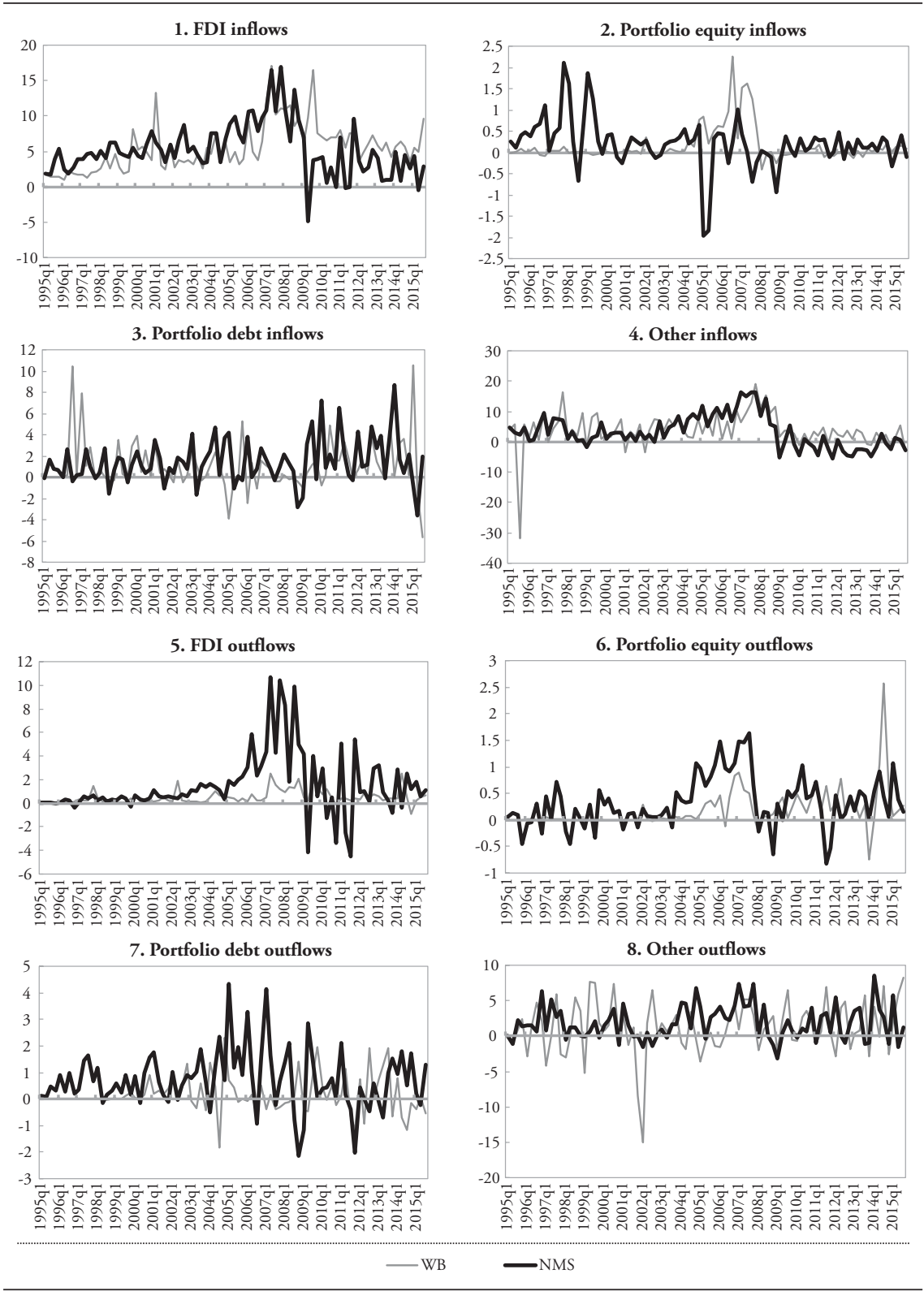

Source: IMF Financial Flow Analytics database. 
Correspondingly, in the early stages of transition, most external liabilities were in the form of external debt. On the external asset side, foreign exchange reserves and other debt assets accounted for the lion's share of Western Balkans' holdings in the 1990s, as in the NMS. The share of equities increased in both assets and liabilities, though it increased later for assets and remains at a lower level, and further behind the NMS (Figure 4).

Figure 4: Equity and Reserves Shares, in \%
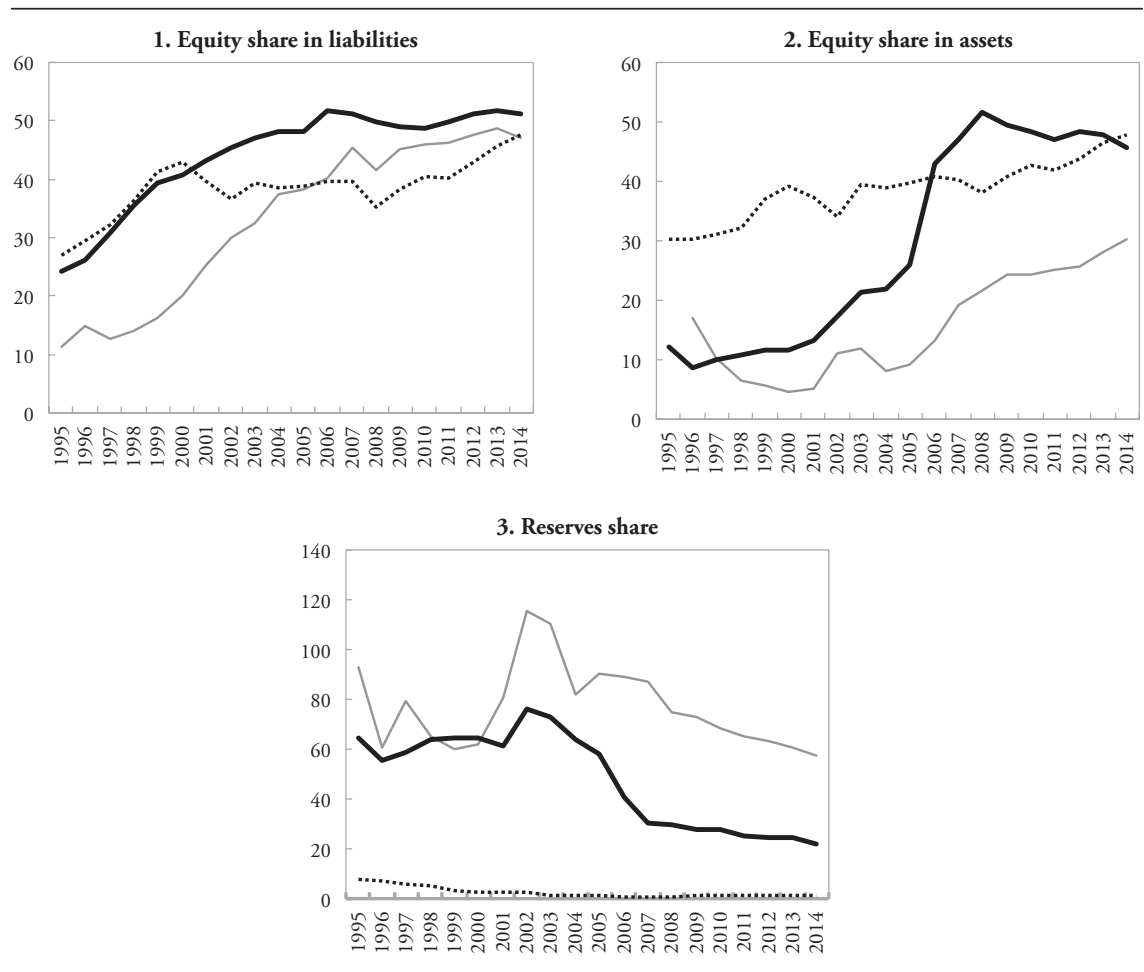

-WB $\longrightarrow$ WMS $\quad \ldots \ldots$ EU-14

Notes: Equity shares refer to shares of equity assets (liabilities) in total external assets (liabilities). Reserves share refers to the ratio of foreign exchange reserves to total external assets.

Source: External Wealth of Nations database. 
Today, liabilities as a percentage of GDP are broadly comparable to the NMS,

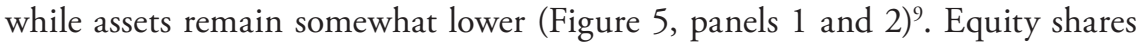
in liabilities are comparable to those in the NMS, while equity shares in assets remain lower (Figure 5, panels 3 and 4).

Figure 5: External Positions in the Western Balkans, the NMS and the EU-14, 2014
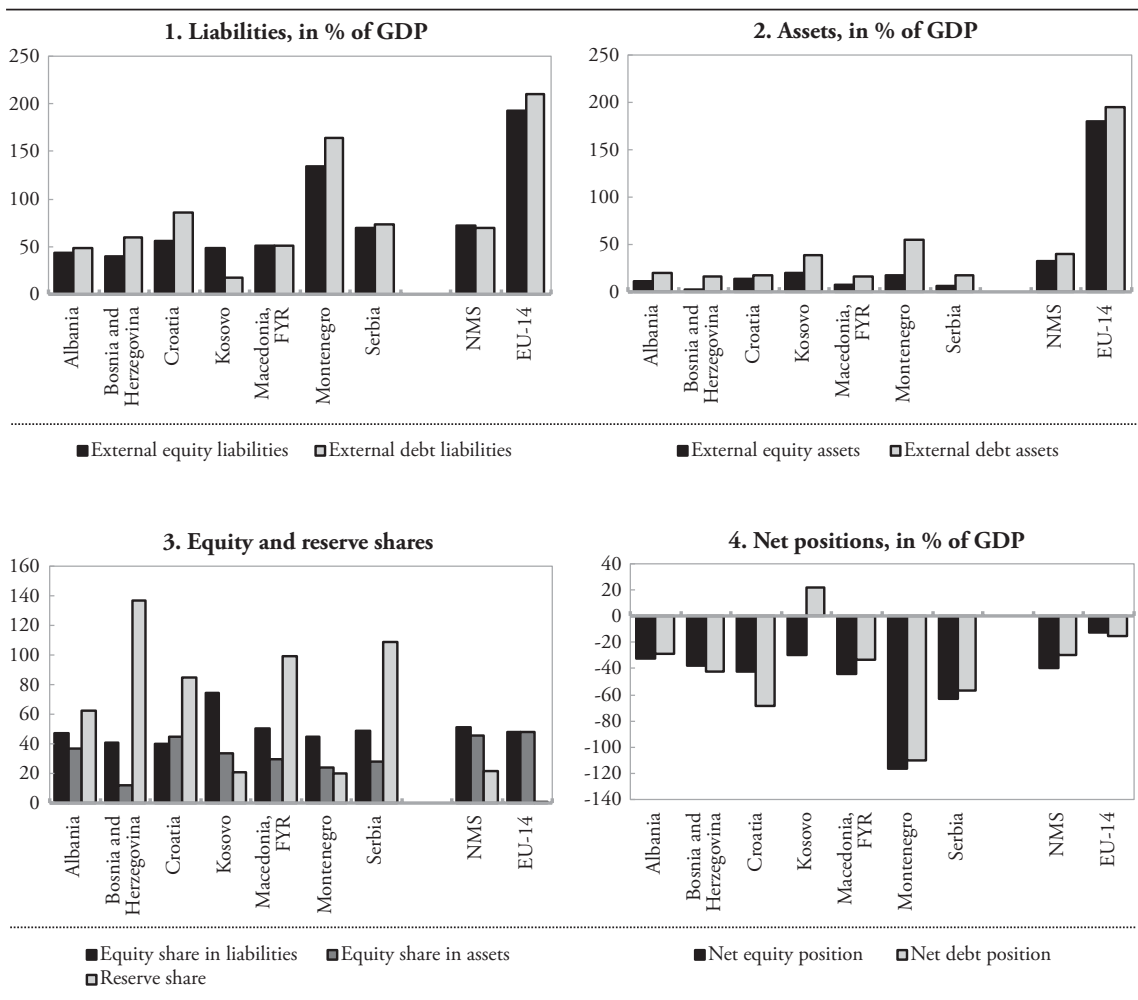

Notes: Equity shares refer to shares of equity assets (liabilities) in total external assets (liabilities). Reserves share refers to the ratio of foreign exchange reserves to total external assets. Net equity (debt) positions refer to equity (debt) assets minus equity (debt) liabilities.

Source: External Wealth of Nations database.

Looking at the evolution of capital flows and external positions in the Western Balkans thus points to important similarities with the NMS. While slightly 9 Within the region, Montenegro is characterized by much higher liabilities and worse net positions, while Kosovo has better net debt positions. 
'late to the game', the Western Balkan economies appear to have caught up rapidly with the NMS (though both regions contain heterogeneity in country experiences within them). Capital flows account for broadly comparable shares of GDP, and consist mainly of FDI and bank lending, though outflows still play a smaller role in the Western Balkans. Equity shares are far above what would be expected given their level of development (Figure 6), and reserve shares are much higher in the Western Balkans than in the NMS.

Figure 6: Equity and Reserve Shares in the Western Balkans and the NMS, by Level of Development

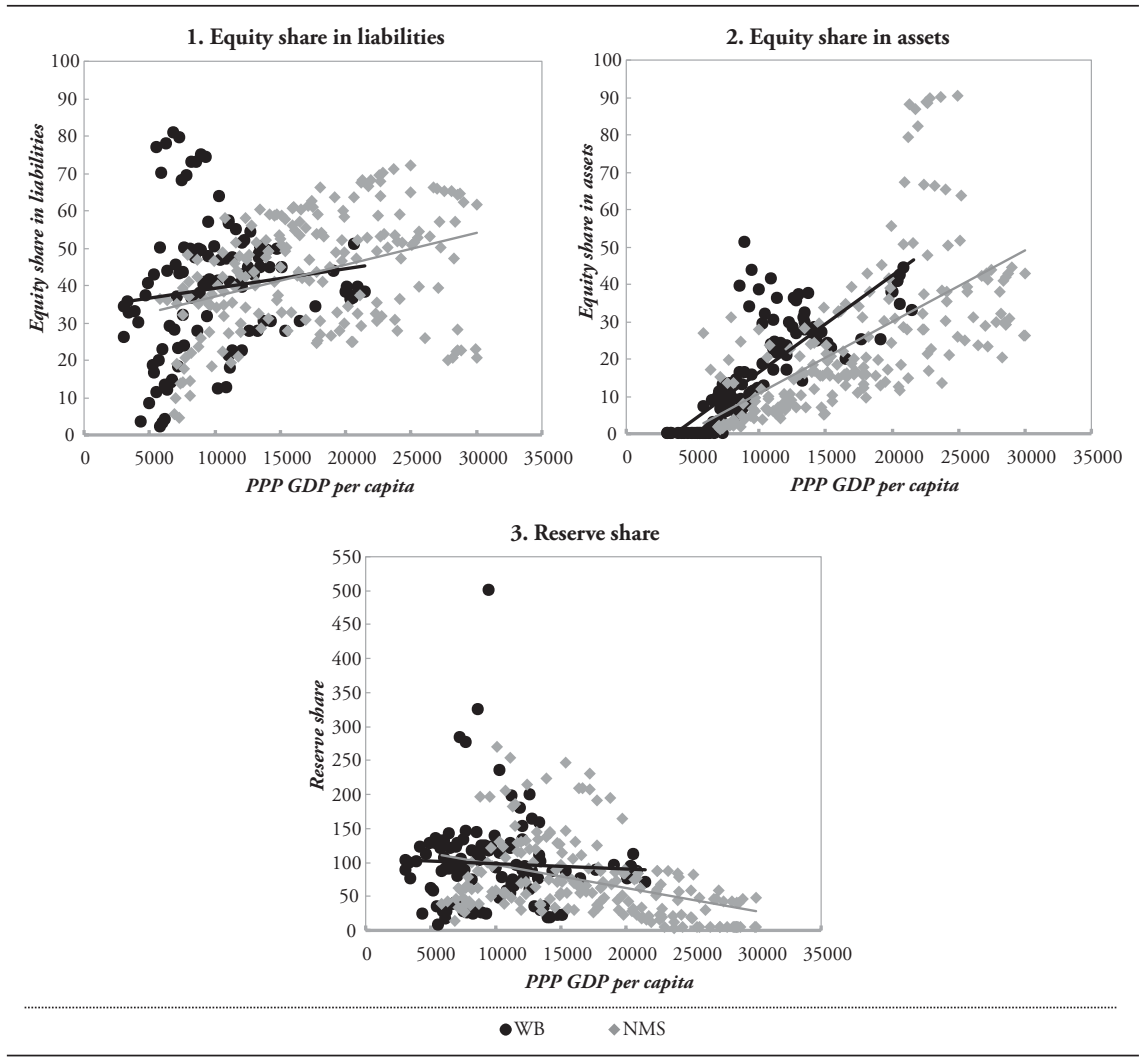

Notes: Equity shares refer to shares of equity assets (liabilities) in total external assets (liabilities). Reserves share refers to the ratio of foreign exchange reserves to total external assets. Dots refer to country-years, including the Western Balkans and the NMS for the period 1995-2014.

Sources: External Wealth of Nations database, World Bank's World Development Indicators dataset, and the IMF World Economic Outlook database. 
These similarities, however, hide a marked difference in capital account openness (Appendix Figure 1). Capital account openness increased in both the Western Balkans and the NMS in the late 1990s and early 2000s, however, while this trend continued in the NMS until the global financial crisis, reaching levels close to those observed in the EU-14, the Western Balkans have, on average, remained much more closed. The relative similarity of capital inflows is thus all the more striking, suggesting that factors such as a skilled, relatively cheap labor force and expectations of potential future EU membership were more important in driving investment decisions than the extent of capital controls.

\section{Determinants of Capital Flows}

Having examined the evolution of external positions and the behavior of capital flows to the Western Balkans, the following section aims to extend the analysis by looking at the determinants of capital flows, examining the role of common factors, as well as structural characteristics and policy frameworks. As discussed above, the empirical frameworks used here are motivated by international investors' optimal portfolio allocation decisions, where investments in a particular country are more desirable the higher the risk-adjusted returns, relative to the returns from investing in other countries.

Two complementary estimation strategies are used ${ }^{10}$. First, we examine the role of common factors in driving capital flows to the region. To do so, average capital flows to the Western Balkans (and for comparison, to the NMS) are regressed on key economic explanatory factors such as the growth differential between the

10 The estimation strategy closely follows that of the IMF (2016a). The macroeconomic variables used in the regressions, such as GDP and capital flows, influence each other in complex ways, making it difficult to obtain clear causal estimates. The main goal of the analysis is therefore to establish robust correlations, examining which variables track the evolution of capital flows more strongly. 
region and the EU-14, interest rates in the EU-14 ${ }^{11}$, global investors' risk appetite (measured using the logarithm of the VXO), and percentage changes in oil prices (controlling also for seasonal dummy variables):

$$
\overline{\text { fflows }_{t}}=\gamma_{0}+\gamma_{1}\left(\bar{g}_{t}^{\text {WB }}-\bar{g}_{t}^{E U 14}\right)+\gamma_{2} \overline{i r}_{t}^{E U 14}+\gamma_{3} \text { riskaversion }_{t}+\gamma_{6} \Delta P_{t}^{\text {oil }}+\varphi \boldsymbol{S}_{t},
$$

in which $\left(\bar{g}_{t}^{W B}-\bar{g}_{t}^{E U 14}\right)$ is the common growth rate differential between the Western Balkans and the EU-14, and $\overline{i r}_{t}^{E U 14}$ is a simple average of real policy rates in the EU-14.

Secondly, the cross-country distribution of gross capital inflows is modeled using a panel regression (with country-fixed effects) of capital inflows on country-specific economic factors, such as country-specific growth differentials, institutions (proxied in the baseline using the WGI measure on the rule of law), capital controls, whether the country is under an IMF program (IMF borrowing is more than 100 percent of its quota and increasing), and percentage changes in the terms of trade (controlling for time-fixed effects):

$$
\begin{aligned}
& \text { Kflows }_{i t}=\theta_{0}+\theta_{1}\left(g_{i t}-\bar{g}_{i t}^{E U 14}\right)+\theta_{2} \text { institutional quality }_{i t}+\theta_{3} \text { capital controls }_{i t}+ \\
& +\theta_{4} \text { IMFloan }_{i t}+\theta_{5} \Delta \text { terms of trade } i t+\tau \boldsymbol{T}_{\boldsymbol{t}}+\varepsilon_{i t},
\end{aligned}
$$

in which $\left(g_{i t}-\bar{g}_{i t}^{E U 14}\right)$ is the growth rate differential between the country's own growth rate and a simple average of EU-14 growth rates, and $\boldsymbol{T}_{\boldsymbol{t}}$ are a set of quarter dummy variables (to account for possible seasonality in the regression framework directly) $)^{12}$.

Within each step, inflows and outflows are examined separately given evidence that gross inflows and gross outflows have in their own right-rather than just

11 Our baseline specification excludes interest rates in the Western Balkans as consistent long time-series are unfortunately difficult to obtain. While for some countries data on policy rates are available, others only have deposit rates. Results are very similar when adding interest rates for the Western Balkans as well (Appendix Tables 1 and 2), with high interest rates in the region often mopping up the effects of increasing global risk aversion. Interest rates are included in levels rather than as differentials, since interest rate differentials are highly collinear with growth differentials and thus difficult to separate empirically.

12 Results are very similar when examining seasonally adjusted series instead. 
in terms of the net gap between them-a distinct importance in determining systemic risk (Avdjiev, McCauley, \& Shin, 2015).

Average growth rate differentials between the Western Balkans and the EU14, interest rates in the EU-14, and global investor risk appetite are estimated to be statistically significant determinants of average capital inflows (Table 1). The results are qualitatively similar for the NMS, with somewhat larger effects of EU-14 interest rates and somewhat smaller effects of the growth differential (though these effects are difficult to separate empirically; Figure 7). These factors also appear to explain more of the variation in the NMS than in the Western Balkans. Examining growth differentials of the Western Balkans relative to the NMS rather than the EU-14 and controlling for interest rates in the NMS yields similar results. EU-14 and NMS growth and interest rates followed similar trends in the period examined here, thus again making it difficult to separate their effects empirically (Figure 7).

Figure 7: Average Growth and Real Interest Rates, in \%

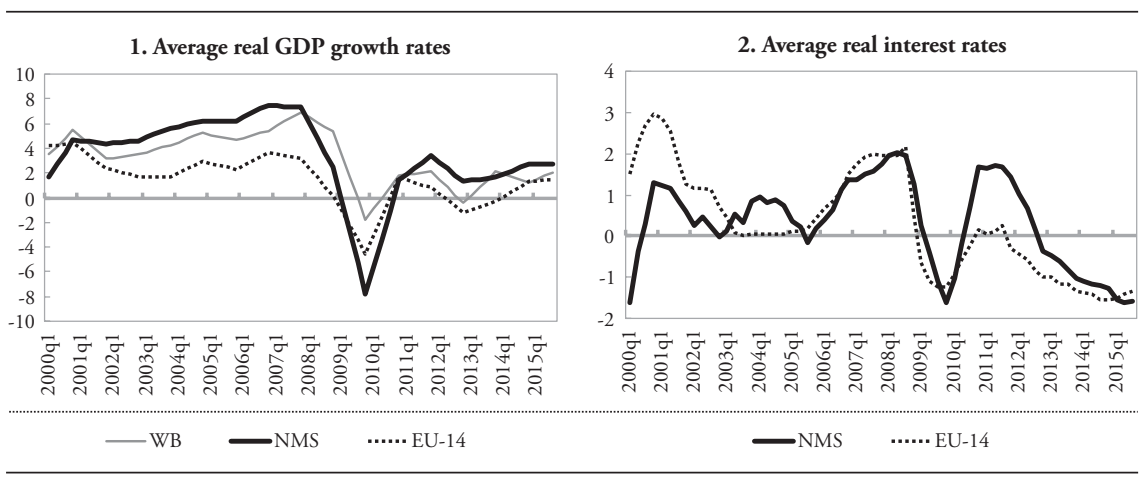

Sources: IMF Global Data Source database and the IMF World Economic Outlook database.

These results are broadly in line with the existing literature on the NMS, which highlighted the role of push factors (a favorable global environment, characterized by declining interest rates, abundant liquidity, low risk aversion, and low global 
volatility produced a willing supply of capital, especially from the EU-15; see Bakker \& Gulde, 2010) and pull factors (the anticipation of rapid growth and high returns, seen as a natural part of the catch-up process and as the result of low wages and low capital-labor ratios, as well as post-transition reforms; see Lipschitz, Lane, \& Mourmouras, 2002).

Table 1: The Role of Global Factors in Explaining Average Gross Capital Inflows

\begin{tabular}{|c|c|c|c|c|}
\hline \multirow[t]{2}{*}{ Growth differential (WB - EU-14) } & $2.648^{* * *}$ & & & $2.203^{* * *}$ \\
\hline & $(0.540)$ & & & $(0.628)$ \\
\hline \multirow[t]{2}{*}{ Growth differential (NMS - EU-14) } & & $1.755^{* * *}$ & & \\
\hline & & $(0.632)$ & & \\
\hline \multirow[t]{2}{*}{ Growth differential (WB - NMS) } & & & $1.152^{* *}$ & 0.571 \\
\hline & & & $(0.564)$ & $(0.540)$ \\
\hline \multirow[t]{2}{*}{ Interest rates (EU-14) } & $2.008^{* * *}$ & $3.684^{* * *}$ & & $1.770^{*}$ \\
\hline & $(0.628)$ & $(0.663)$ & & $(0.998)$ \\
\hline \multirow[t]{2}{*}{ Interest rates (NMS) } & & & $3.406^{* * *}$ & 1.024 \\
\hline & & & $(0.880)$ & $(0.860)$ \\
\hline \multirow[t]{2}{*}{ Global risk aversion (log) } & $-3.783^{*}$ & $-5.785^{* * *}$ & -4.342 & -5.150 \\
\hline & $(2.146)$ & $(2.117)$ & $(2.818)$ & $(3.188)$ \\
\hline \multirow[t]{2}{*}{ Change in the oil price } & -0.0142 & 0.0348 & -0.00646 & -0.0194 \\
\hline & $(0.0312)$ & $(0.0270)$ & $(0.0288)$ & $(0.0341)$ \\
\hline Sample & WB & NMS & WB & WB \\
\hline Number of obs. & 63 & 63 & 63 & 63 \\
\hline Adjusted R-squared & 0.325 & 0.572 & 0.192 & 0.318 \\
\hline
\end{tabular}

Notes: ${ }^{*}$ denotes significance at 10 percent; ${ }^{* *}$ denotes significance at 5 percent; ${ }^{* * *}$ denotes significance at 1 percent. Seasonal dummy variables and a constant are included but not reported.

Source: Author's calculations.

To gauge the economic significance of the explanatory variables, panels 1 and 2 in Figure 8 compare actual average capital inflows to the Western Balkans with predictions from this regression and contributions from each explanatory variable. Corresponding results for the NMS are reported in panels 3 and 4.

Panels 1 and 3 point to a tight empirical link between the actual and predicted capital inflows. Panels 2 and 4 suggest that the decline in inflows shows a strong association with the shrinking real GDP growth differential relative to the 
EU-14. Diminished growth prospects counterbalance the effect of decreasing risk aversion, which would predict an increase in capital inflows during this period ${ }^{13}$.

Figure 8: The Role of Common Factors for Capital Inflows
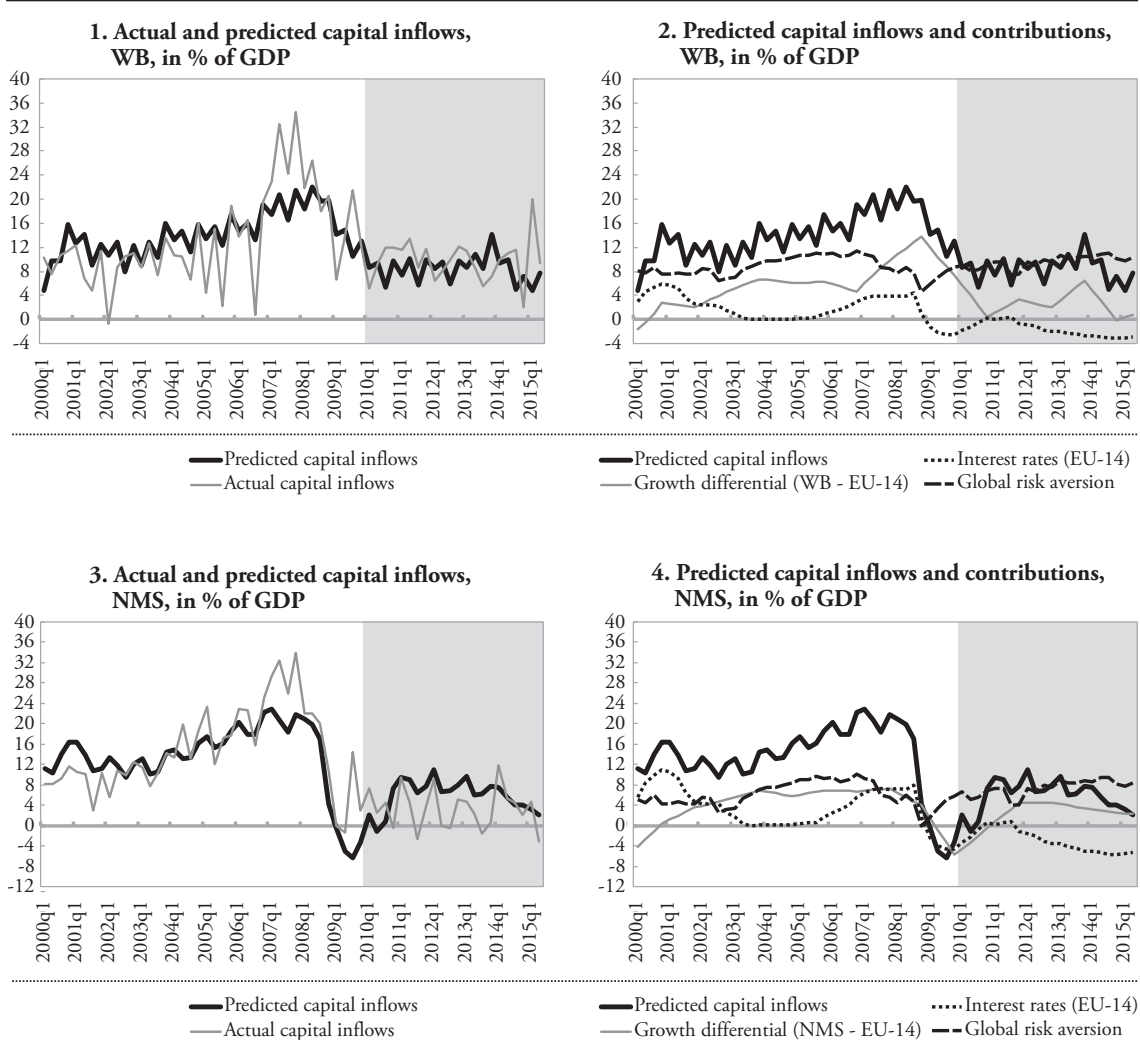

Notes: Average capital flows are regressed on growth differentials, advanced economy interest rates, global risk aversion, the change in the oil price, and seasonal dummies. Contributions of the change in the oil price are very small and thus not reported. Predicted capital flows refer to the predicted values from this regression.

Sources: Fernandez, Klein, Rebucci, Schindler, and Uribe (2015), IMF Financial Flow Analytics database, Global Data Source, Haver Analytics, IMF World Economic Outlook database, and the World Bank's World Governance Indicators dataset.

13 Regression specifications, as outlined in the beginning of section five, include seasonal dummy variables. Their effects are statistically significant and are included in the predicted values shown in Figures 8 and 9. 
Predictions underestimate the boom to a certain extent both in the Western Balkans as well as in the NMS, possibly pointing to some overoptimism, beyond what was warranted purely based on growth and interest rate differentials. On average, they match the slowdown in capital inflows since 2007 in the Western Balkans quite well, though they appear to overpredict capital inflows to the NMS, suggesting that, perhaps, it is not inflows to the Western Balkans that held up unusually well, but flows to the NMS, which underperformed relative to what could have been expected given the past relationship of capital flows to growth and interest rate differentials - perhaps as a natural consequence of the catch-up process to the EU-15. Continued FDI inflows to the Western Balkans could also have included finalizations of projects launched before the start of the global financial crisis, as well as some new greenfield investments that continue to be attracted by lower factor costs and in some cases, lower exchange rates (see also Jevčák et al., 2010) ${ }^{14}$. In terms of cross-country variation, better governance and competition policy have been associated with smaller drops in capital flows. The relative illiquidity of assets may also have mitigated foreign investors' ability to withdraw capital quickly.

Figure 9 presents symmetric results for capital outflows, with the regression results reported in Table 2. Outflows from the Western Balkans have been volatile and appear hard to predict using these explanatory variables, with seasonality dominating the predicted values ${ }^{15}$. As noted earlier, outflows are still much lower in the Western Balkans than in the NMS, with fewer domestic institutional investors. Predictions for the NMS do somewhat better, capturing the pick-up in outflows that accompanied the increase in inflows in the boom years. Global risk aversion appears to be the key driver of outflows from the NMS.

14 An in-depth analysis of the pull factors for FDI flows is outside the scope of this paper.

15 As expected, seasonally adjusted series, as well as predicted values excluding the effects of the seasonal dummies are much smoother and show no clear pattern over time. 
Table 2: The Role of the Global Factors in Explaining Average Gross Capital Outflows

\begin{tabular}{|c|c|c|c|c|}
\hline \multirow[t]{2}{*}{ Growth differential (WB - EU-14) } & 0.219 & & & 0.0295 \\
\hline & $(0.291)$ & & & $(0.354)$ \\
\hline \multirow[t]{2}{*}{ Growth differential (NMS - EU-14) } & & 0.508 & & \\
\hline & & $(0.350)$ & & \\
\hline \multirow[t]{2}{*}{ Growth differential (WB - NMS) } & & & $0.453^{*}$ & 0.421 \\
\hline & & & $(0.258)$ & $(0.278)$ \\
\hline \multirow[t]{2}{*}{ Interest rates (EU-14) } & -0.377 & $1.347^{* * *}$ & & -0.209 \\
\hline & $(0.455)$ & $(0.501)$ & & $(0.490)$ \\
\hline \multirow[t]{2}{*}{ Interest rates (NMS) } & & & 0.0295 & 0.141 \\
\hline & & & $(0.366)$ & $(0.514)$ \\
\hline \multirow[t]{2}{*}{ Global risk aversion (log) } & 0.164 & $-5.792^{* * *}$ & -1.188 & -0.962 \\
\hline & $(1.344)$ & $(1.293)$ & $(1.494)$ & $(1.939)$ \\
\hline \multirow[t]{2}{*}{ Change in the oil price } & 0.00103 & 0.00196 & -0.00644 & -0.00409 \\
\hline & $(0.0164)$ & $(0.0183)$ & $(0.0152)$ & $(0.0171)$ \\
\hline Sample & WB & NMS & WB & WB \\
\hline Number of obs. & 63 & 63 & 63 & 63 \\
\hline Adjusted R-squared & 0.242 & 0.393 & 0.264 & 0.239 \\
\hline
\end{tabular}

Notes: ${ }^{*}$ denotes significance at 10 percent; ${ }^{* *}$ denotes significance at 5 percent; ${ }^{* * *}$ denotes significance at 1 percent. Seasonal dummy variables and a constant are included but not reported.

Source: Author's calculations.

While these results point to the role of common factors, their importance depends on policy characteristics that are country-specific (Figure 10). Results are qualitatively similar in the Western Balkans and the NMS:

- Economies that are financially more open appear more exposed to the common trend in capital inflows to the region: a higher share of the total variance of capital inflows is explained by the common time effect (controlling for differences in countries' growth performance) in countries with more open capital accounts.

- Larger, less financially developed, less liquid countries are also less exposed to common trends, in line with the results of Eichengreen and Gupta (2014). 
Figure 9: The Role of Common Factors for Capital Outflows
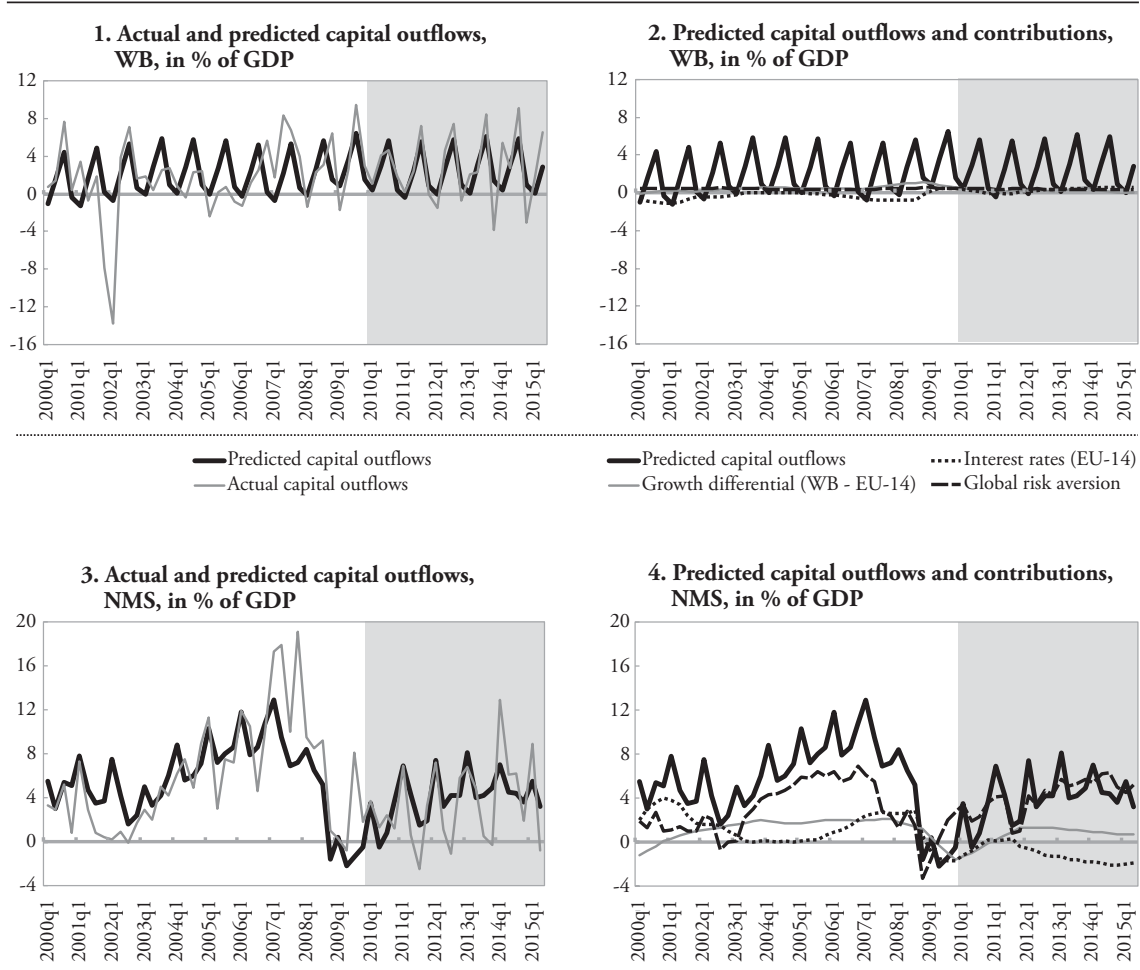

$$
\begin{aligned}
& \text { Predicted capital outflows } \\
& \text { - Actual capital outflows }
\end{aligned}
$$

-Predicted capital outflows
— Growth differential (NMS - EU-... Interest rates (EU-14)

Notes: Average capital flows are regressed on growth differentials, advanced economy interest rates, global risk aversion, the change in the oil price, and seasonal dummies. Contributions of the change in the oil price are very small and thus not reported. Predicted capital flows refer to the predicted values from this regression.

Sources: Fernandez et al. (2015), IMF Financial Flow Analytics database, Global Data Source, Haver Analytics, IMF World Economic Outlook database, and the World Bank's World Governance Indicators dataset.

- More flexible exchange rates also reduce the share of the total variance of capital inflows explained by common factors ${ }^{16}$. Countries that have flexible exchange rate regimes would tend to see immediate currency depreciations

16 A large literature has studied the effectiveness of the exchange rate as a shock absorber. There is scarce evidence, however, on its role in smoothing the global capital flow cycle. Magud, Reinhart, and Vesperoni (2014) provide evidence that exchange rate flexibility smoothens the domestic credit cycle but find no evidence that exchange rate flexibility dampens capital flows per se in their regression analysis. 
in response to a broader downward trend in the supply of capital. By making domestic assets cheaper, a weaker currency would tend to attract capital into the country. Thus, exchange rate flexibility would reduce the sensitivity of capital inflows to global factors ${ }^{17}$.

- Countries that have higher reserves and lower public debt tend to have a lower percentage of the fluctuations in capital inflows attributable to common factors. Because higher reserves and lower public debt reduce country risk, foreign investors would be less tempted to pull out from countries with those characteristics, making their capital inflows more resilient to shifts in the global factor affecting all the emerging market economies.

Figure 10: Share of Variation in Total Capital Inflows Explained by Global Factors, in \%

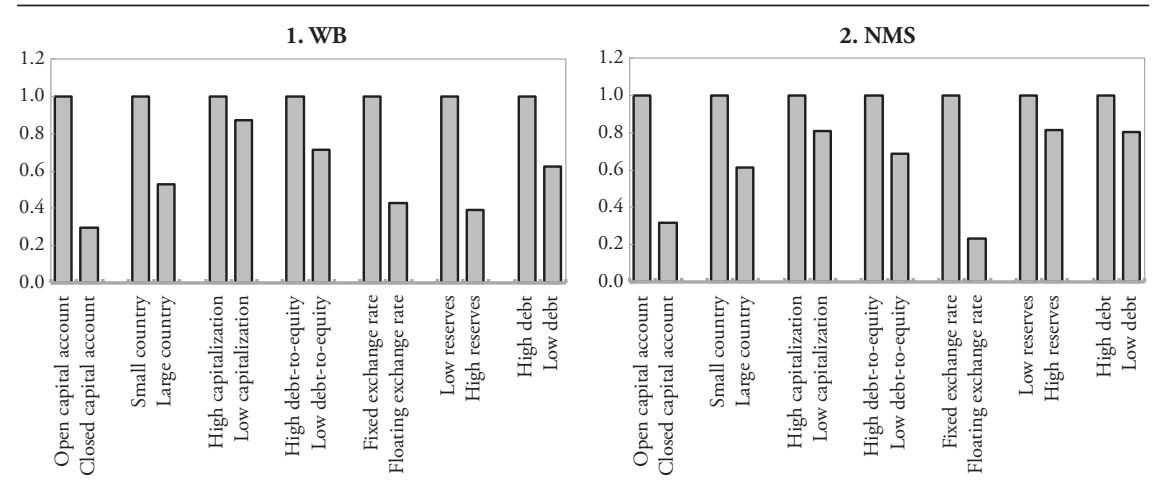

Notes: R-squares form a regression of capital inflows on average capital inflows, normalized using within-group standard deviations of flows; base group set to 1. Fernandez et al. (2015) measure for controls on capital inflows; split at 0.5. Fixed and floating exchange rates are defined using the IMF's AREAER classification. High and low reserves are measured in months of imports and are split at the sample median. High and low government debt is split at the sample median.

Sources: Fernandez et al. (2015), IMF Financial Flow Analytics database, IMF AREAER database, and the IMF World Economic Outlook database.

17 It should, however, be added that the classification used here refers to de facto exchange rate regimes. Examining effective exchange rate flexibility using the Calvo and Reinhart (2002) 'fear of floating' index suggests that no currency in the Western Balkans is effectively floating, with the partial exception of Serbia (IMF, 2016b). While the larger variance explained by common factors for peggers could be driven by differences in the composition of flows (in the NMS peggers attracted more bank flows than floaters, especially during the boom years, while floaters attracted more FDI; see IMF, 2016b), there does not seem to be a clear distinction in the Western Balkans in this respect. 
The second step of the analysis focuses on the role of structural characteristics and policies in shaping the dynamics of capital flows to the Western Balkans. To this end, the section uses a panel-data specification that relates countryspecific capital flows to: country-specific growth differentials, an indicator of institutional quality, the degree to which capital inflows are restricted by law, whether the country is under a large IMF-sponsored adjustment program, changes in its terms of trade, and time-fixed effects. The regression (shown in Table 3), results in positive and significant coefficients on the growth differential and institutional quality ${ }^{18}$. Baseline regressions are based on an unbalanced panel for the period 2000-2015. Since the global financial crisis could have affected the responses of capital flows to changes in various characteristics, a robustness check examined the same regression, while excluding the years 2007, 2008, and 2009. As expected, the growth differential is still highly significant (now for both the Western Balkans and the NMS), while institutional quality is no longer significant, but still large and positive. Results are robust to controlling for workers' remittances as a share of GDP, which-although large for Albania, Bosnia and Herzegovina, Kosovo, and Serbia-does not have a significant effect on capital flows for the region as a whole. Results are similar in sign and magnitude, though not statistically significant for the NMS. Country-bycountry time series regressions, however, point to considerable heterogeneity across countries in the association between growth and capital flows (Figure 11), with the effect being largest in Montenegro, but also particularly large in Serbia and Bosnia and Herzegovina.

18 Baseline regressions use the WGI 'rule of law' measure. Results are qualitatively similar when using alternative measures of institutions such as the International Country Risk Guide (ICRG) measure of the 'quality of the bureaucracy'. 
Figure 11: Cross-Country Variation in the Association Between Growth and Capital Inflows

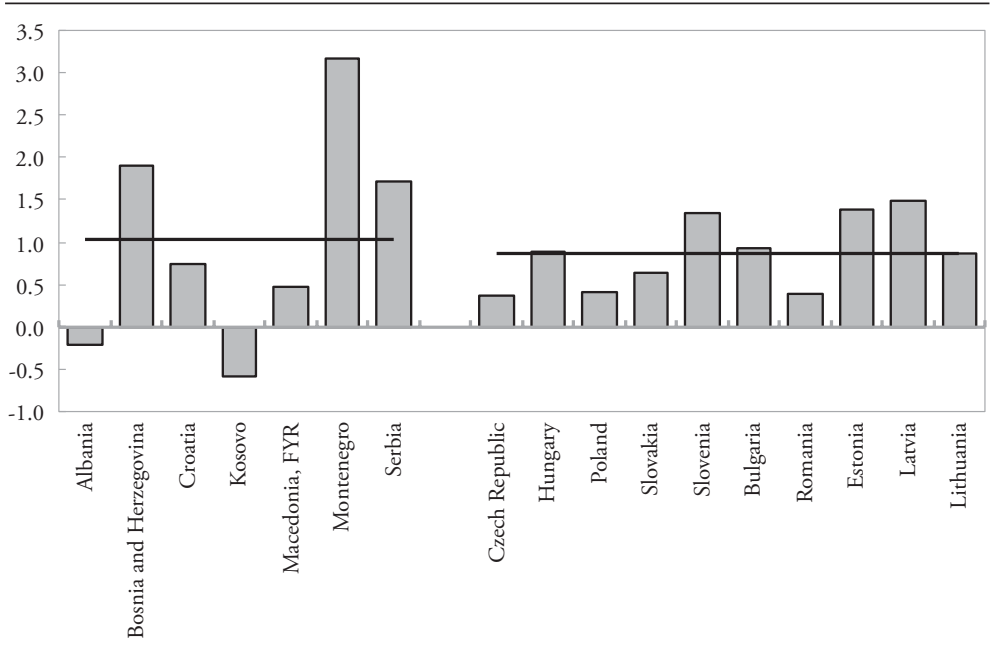

Note: Coefficient estimates based on country-by-country regressions of capital inflows on real GDP growth. Sources: IMF Financial Flow Analytics databse and the IMF World Economic Outlook database.

Table 3: The Role of Country-Specific Factors in Explaining Gross Capital Inflows

\begin{tabular}{l|c|c}
\hline Growth differential (country - EU-14) & $0.618^{*}$ & 0.660 \\
\cline { 2 - 3 } & $(0.213)$ & $(0.530)$ \\
\hline Institutional quality & $17.64^{*}$ & 12.46 \\
\hline Capital account openness & $(6.147)$ & $(7.279)$ \\
\hline IMF program & -0.580 & 1.031 \\
& $(0.924)$ & $(0.869)$ \\
\hline Change in terms of trade & 7.010 & 2.996 \\
\hline Sample & $(3.772)$ & $(3.922)$ \\
\hline Number of obs. & 0.0925 & -0.00867 \\
\hline Adjusted R-squared & $(0.312)$ & $(0.374)$ \\
\hline
\end{tabular}

Notes: ${ }^{*}$ denotes significance at 10 percent; ${ }^{* *}$ denotes significance at 5 percent; ${ }^{* * *}$ denotes significance at 1 percent. Seasonal dummy variables and a constant are included but not reported.

Source: Author's calculations. 
Table 4: The Role of Country-Specific Factors in Explaining Gross Capital Outflows

\begin{tabular}{l|c|c}
\hline Growth differential (country - EU-14) & $0.542^{*}$ & -0.279 \\
\hline Institutional quality & $(0.192)$ & $(0.509)$ \\
& $1.962^{*}$ & 8.637 \\
\hline Capital account openness & $(0.776)$ & $(5.072)$ \\
& 0.0413 & 1.222 \\
IMF program & $(1.084)$ & $(0.695)$ \\
& 0.781 & -0.0673 \\
Change in terms of trade & $(1.340)$ & $(1.774)$ \\
& 0.111 & -0.260 \\
\hline Sample & $(0.129)$ & $(0.305)$ \\
\hline Number of obs. & WB & NMS \\
Adjusted R-squared & 220 & 560 \\
\hline
\end{tabular}

Notes: ${ }^{*}$ denotes significance at 10 percent; ${ }^{* *}$ denotes significance at 5 percent; ${ }^{* * *}$ denotes significance at 1 percent. Seasonal dummy variables and a constant are included but not reported.

Source: Author's calculations.

\section{Conclusions and Policy Recommendations}

The Western Balkans have witnessed dramatic changes over the past 25 years. Financial integration took off somewhat later than in the NMS, but has increased rapidly, despite still much lower capital account openness. Capital inflows as a share of GDP are comparable to those observed in the NMS and are perhaps surprisingly diverse in terms of source countries. In both regions, FDI and bank lending account for the bulk of inflows as well as outflows (though the latter are still small in the Western Balkans), while shares of equity assets in total external assets are much higher than they were in the NMS at comparable levels of development.

Similar to the experience of the NMS, the region experienced booming inflows in 2003-2007, driven by a combination of push and pull factors: a willing supply of funds from Western Europe and expectations of high growth in emerging Europe. Booming inflows provided financing and supported private sector development and employment, however, their sharp drop-a result of the global 
financial crisis-and strong link with growth, point to vulnerabilities. So far, inflows to the Western Balkans have held up better than in the NMS, however, the similarities in terms of their determinants point to caution: capital inflows are pro-cyclical, thus potentially raising vulnerabilities by amplifying external shocks.

While the paper highlighted the roles of external factors, it also illustrated that individual country characteristics-including growth and interest rate differentials, but also institutions and policies, the level of reserves, public debt and the degree of exchange rate flexibility-do play a role in affecting capital inflows.

Given the especially strong link between growth and capital flows in the region and shrinking growth differentials relative to advanced economies, such policies and institutions become increasingly important to continue attracting muchneeded inflows. Alongside the continued search for new, sustainable sources of growth, countries should implement prudent fiscal policies to reduce country risk, and proactive macroprudential policies to limit currency mismatches and hence, the ramifications of a slowdown in inflows. Exchange rate flexibility (where available) can also help act as a shock absorber. 


\section{Appendix Figures}

Appendix Figure 1: Source of Portfolio Inflows, from Selected Regions and Countries, \% of Total Inflows

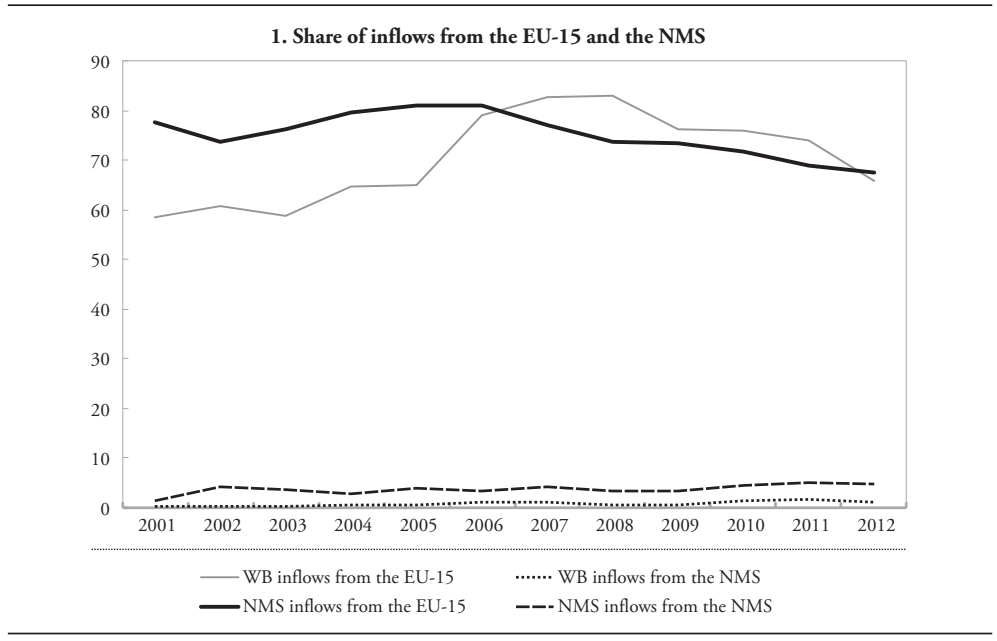

2. Share of portfolio inflows to the Western Balkans from selected countries, in \%

\begin{tabular}{|c|c|c|c|c|c|c|}
\hline & Albania & $\begin{array}{c}\text { Bosnia and } \\
\text { Herzegovina }\end{array}$ & Croatia & $\begin{array}{c}\text { FYR } \\
\text { Macedonia }\end{array}$ & Montenegro & Serbia \\
\hline Austria & 0,9 & 5,6 & 15,3 & 10,8 & 10,8 & 4,0 \\
\hline Belgium & 5,5 & 0,0 & 0,4 & 0,3 & 0,2 & 0,7 \\
\hline Denmark & 0,4 & 7,9 & 1,0 & 4,7 & 1,6 & 0,7 \\
\hline France & 7,6 & 0,5 & 5,0 & 0,4 & 12,8 & 2,3 \\
\hline Germany & 2,3 & 2,9 & 18,4 & 14,3 & 2,5 & 10,3 \\
\hline Greece & 24,0 & 0,0 & 0,5 & 3,9 & 0,0 & 12,8 \\
\hline Ireland & 7,5 & 1,5 & 2,7 & 5,9 & 5,6 & 1,2 \\
\hline Italy & 22,6 & 4,8 & 3,3 & 2,2 & 0,6 & 1,6 \\
\hline Luxembourg & 10,4 & 30,5 & 13,3 & 18,0 & 37,9 & 15,9 \\
\hline Portugal & 0,0 & 0,0 & 0,2 & 0,0 & 0,0 & 8,4 \\
\hline Spain & 0,0 & 0,0 & 0,1 & 0,0 & 0,0 & 0,0 \\
\hline UK & 3,9 & 5,8 & 9,9 & 4,0 & 1,2 & 11,5 \\
\hline NMS & 0,3 & 0,1 & 2,2 & 0,3 & 1,5 & 0,8 \\
\hline Russia & 0,0 & 0,0 & 0,0 & 0,1 & 1,4 & 0,7 \\
\hline
\end{tabular}

Notes: Data not available for the Netherlands on the sending side, and Kosovo on the receiving side. Panel 2 refers to averages over 2001-2012.

Source: IMF Coordinated Portfolio Investment Survey. 
Appendix Figure 2: Financial Integration and Capital Account Openness

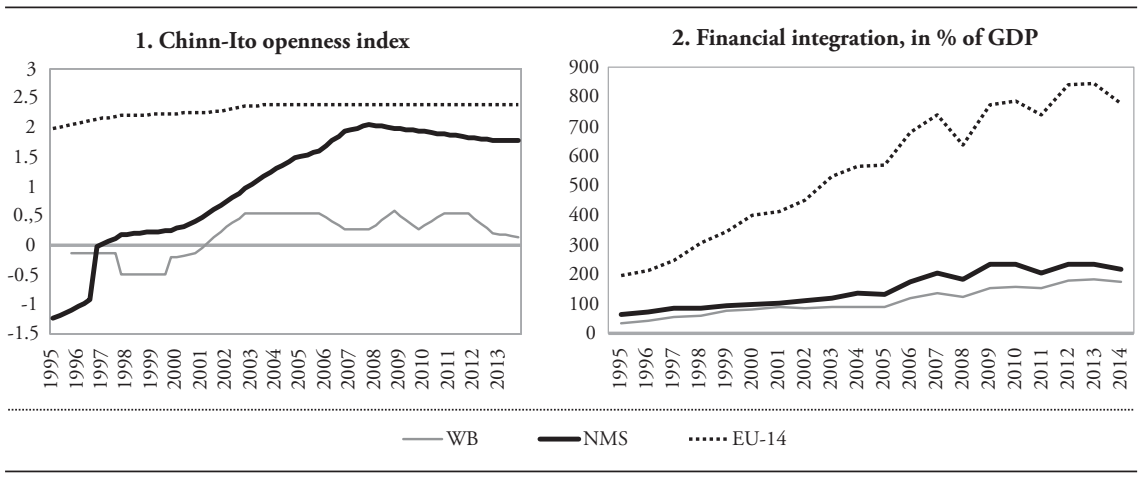

Sources: External Wealth of Nations database and Chinn and Ito (2006).

\section{Appendix Tables}

Appendix Table 1: The Role of Global Factors in Explaining Average Gross Capital Inflows

\begin{tabular}{|c|c|c|c|c|}
\hline \multirow[t]{2}{*}{ Growth differential (WB - EU-14) } & $2.138^{* * *}$ & & & $1.967^{* * *}$ \\
\hline & $(0.625)$ & & & $(0.601)$ \\
\hline \multirow[t]{2}{*}{ Growth differential (NMS - EU-14) } & & $1.765^{* * *}$ & & \\
\hline & & $(0.650)$ & & \\
\hline \multirow[t]{2}{*}{ Growth differential (WB - NMS) } & & & 0.885 & 0.437 \\
\hline & & & $(0.713)$ & $(0.550)$ \\
\hline \multirow[t]{2}{*}{ Interest rates (EU-14) } & $3.577^{* * *}$ & $3.697^{* * *}$ & $4.695^{* * *}$ & (omitted) \\
\hline & $(1.071)$ & $(0.955)$ & $(1.076)$ & \\
\hline \multirow[t]{2}{*}{ Interest rates (NMS) } & & -0.0661 & & \\
\hline & & $(0.957)$ & & \\
\hline \multirow[t]{2}{*}{ Interest rates (WB) } & $-1.764^{* * *}$ & & $-2.428^{* * *}$ & (omitted) \\
\hline & $(0.645)$ & & $(0.648)$ & \\
\hline \multirow[t]{2}{*}{ Global risk aversion $(\log )$} & -1.083 & $-5.799^{* * *}$ & -1.363 & -2.243 \\
\hline & $(2.028)$ & $(1.678)$ & $(2.827)$ & $(2.622)$ \\
\hline \multirow[t]{2}{*}{ Change in the oil price } & -0.0109 & 0.0341 & -0.0168 & -0.0164 \\
\hline & $(0.0303)$ & $(0.0282)$ & $(0.0296)$ & $(0.0266)$ \\
\hline Sample & WB & NMS & WB & WB \\
\hline Number of obs. & 63 & 63 & 63 & 63 \\
\hline Adjusted R-squared & 0.425 & 0.562 & 0.319 & 0.424 \\
\hline
\end{tabular}

Notes: ${ }^{*}$ denotes significance at 10 percent; ${ }^{* *}$ denotes significance at 5 percent; ${ }^{* * *}$ denotes significance at 1 percent. Seasonal dummy variables and a constant are included but not reported.

Source: Author's calculations. 
Appendix Table 2: The Role of Global Factors in Explaining Average Gross Capital Outflows

\begin{tabular}{|c|c|c|c|c|}
\hline \multirow[t]{2}{*}{ Growth differential (WB - EU-14) } & -0.0956 & & & -0.265 \\
\hline & $(0.368)$ & & & $(0.317)$ \\
\hline \multirow{2}{*}{ Growth differential (NMS - EU-14) } & & 0.453 & & \\
\hline & & $(0.296)$ & & \\
\hline \multirow[t]{2}{*}{ Growth differential (WB - NMS) } & & & 0.371 & $0.432^{*}$ \\
\hline & & & $(0.266)$ & $(0.257)$ \\
\hline \multirow[t]{2}{*}{ Interest rates (EU-14) } & 0.574 & $1.237^{* * *}$ & 0.736 & (omitted) \\
\hline & $(0.625)$ & $(0.416)$ & $(0.478)$ & \\
\hline \multirow[t]{2}{*}{ Interest rates (NMS) } & & 0.242 & & \\
\hline & & $(0.554)$ & & \\
\hline \multirow[t]{2}{*}{ Interest rates (WB) } & $-1.068^{* * *}$ & & $-1.007^{* * *}$ & (omitted) \\
\hline & $(0.399)$ & & $(0.424)$ & \\
\hline \multirow[t]{2}{*}{ Global risk aversion (log) } & 1.754 & $-5.915^{* * *}$ & 0.491 & 0.609 \\
\hline & $(1.497)$ & $(1.277)$ & $(1.800)$ & $(1.570)$ \\
\hline \multirow[t]{2}{*}{ Change in the oil price } & -0.00291 & 0.00201 & -0.00257 & -0.00261 \\
\hline & $(0.0195)$ & $(0.0173)$ & $(0.0158)$ & $(0.0153)$ \\
\hline Sample & WB & NMS & WB & WB \\
\hline Number of obs. & 63 & 63 & 63 & 63 \\
\hline Adjusted R-squared & 0.323 & 0.381 & 0.346 & 0.340 \\
\hline
\end{tabular}

Notes: ${ }^{*}$ denotes significance at 10 percent; ${ }^{* *}$ denotes significance at 5 percent; ${ }^{* * *}$ denotes significance at 1 percent. Seasonal dummy variables and a constant are included but not reported.

Source: Author's calculations. 


\section{Literature}

Ahmed, S., \& Zlate, A. (2013). Capital flows to emerging market economies: A brave new world? International Finance Discussion Paper No. 1081. Washington, DC: Board of Governors of the Federal Reserve System.

Árvai, Z. (2005). Capital account liberalization, capital flow patterns, and policy responses in the EU's New Member States. IMF Working Paper No. 05/213. Washington, DC: International Monetary Fund.

Avdjiev, S., McCauley, R. N., \& Shin, H. S. (2015). Breaking free of the triple coincidence in international finance. BIS Working Paper No. 524. Basel: Bank for International Settlements.

Bakker, B. B., \& Gulde, A-M. (2010). The credit boom in the EU New Member States: Bad luck or bad policies? IMF Working Paper No. 10/130. Washington, DC: International Monetary Fund.

Brixiova, Z., Cartia, L, \& Wörgötter, A. (2010). Capital flows and the boombust cycle: The case of Estonia. Economic Systems, 34(1), 55-72. doi: https://doi. org/10.1016/j.ecosys.2009.11.002

Broner, F., Didier, T., Erce, A., \& Schmukler, S. L. (2013). Gross capital flows: Dynamics and crises. Journal of Monetary Economics, 60, 113-133.

Buch, C. M., \& Piazolo, D. (2001). Capital and trade flows in Europe and the impact of enlargement. Economic Systems, 25(3), 183-214. doi: https://doi. org/10.1016/S0939-3625(01)00019-X

Calvo, G. A., \& Reinhart, C. M. (2002). Fear of floating. The Quarterly Journal of Economics, 117(2),379-408.doi:https://doi.org/10.1162/003355302753650274

Cardarelli, R., Elekdag, S., \& Kose, M. A. (2010). Capital inflows: Macroeconomic implications and policy responses. Economic Systems, 34(4), 333-356. doi: https://doi.org/10.1016/j.ecosys.2010.01.004 
Chinn, M. D., \& Ito, H. (2006). What matters for financial development? Capital controls, institutions, and interactions. Journal of Development Economics, 81(1), 163-192. doi: https://doi.org/10.1016/j.jdeveco.2005.05.010

Claessens, S., Oks, D, \& Polastri, R. (2000). Capital flows to Central and Eastern Europe and the former Soviet Union. In: S. Edwards (Ed.), Capital flows and the emerging economies: Theory, evidence, and controversies (pp. 299-339). Chicago, IL: University of Chicago Press.

Eichengreen, B., \& Gupta, P. (2014). Tapering talk: The impact of expectations of reduced Federal Reserve security purchases on emerging markets. Policy Research Working Paper No. 6754. Washington, DC: The World Bank.

Estrin, S., \& Uvalic, M. (2014). FDI into transition economies: Are the Balkans different? Economics of Transition, 22(2), 281-312. doi: https://doi.org/10.1111/ ecot. 12040

Estrin, S., \& Uvalic, M. (2016). Foreign Direct Investment in the Western Balkans: What role has it played during transition? Comparative Economic Studies, 58(3), 455-483. doi: https://doi.org/10.1057/ces.2016.10

External Wealth of Nations database. Updated and extended version of the dataset constructed by Lane and Milesi-Ferretti (2007). Retrieved from: http://www. philiplane.org/EWN.html.

Fernandez, A., Klein, M. W., Rebucci, A., Schindler, M., \& Uribe, M. (2015). Capital control measures: A new dataset. NBER Working Paper No. 20970. Dataset retrieved from: https://www.nber.org/papers/w20970.

Gabrisch, H. (2015). Net capital flows to and the real exchange rate of Western Balkan countries. Economic Annals, 60(205), 31-52. doi: https://doi.org/10.2298/ EKA1505031G

Ganić, M. (2013). The integration of Western Balkan economies in global economic flows. Unpublished paper. Retrieved from: http://papers.ssrn.com/sol3/papers. cfm?abstract_id=2382459. 
Globan, T. (2015). Financial integration, push factors and volatility of capital flows: Evidence from EU New Member States. Empirica, 42(3), 643-672. doi: https://doi.org/10.1007/s10663-014-9270-2

Haver Analytics. Retrieved from: http://www.haver.com/.

Hegerty, S. W. (2009). Capital inflows, exchange market pressure, and credit growth in four transition economies with fixed exchange rates. Economic Systems, 33(2), 155-167.

International Monetary Fund (IMF). Coordinated Portfolio Investment Survey (CPIS) database. Retrieved from: http://data.imf.org/?sk=B981B4E3-4E58467E-9B90-9DE0C3367363.

International Monetary Fund (IMF). Financial Flow Analytics database.

International Monetary Fund (IMF). Global Data Source database.

International Monetary Fund (IMF). IMF AREAER database. Retrieved from: https://www.elibrary-areaer.imf.org/Pages/Home.aspx.

International Monetary Fund (IMF). World Economic Outlook database. Retrieved from: https://www.imf.org/en/Publications/SPROLLS/world-economicoutlook-databases.

International Monetary Fund (IMF). (2016a). Understanding the slowdown in capital flows to emerging markets. In World economic outlook: Too slow for too long (pp. 63-98). Washington, DC: International Monetary Fund.

International Monetary Fund (IMF). (2016b). Taking stock of monetary and exchange rate regimes in Emerging Europe. Washington, DC: International Monetary Fund.

Jevčák, A, Setzer, R., \& Suardi, M. (2010). Determinants of capital flows to the New EU Member States before and during the financial crisis. Economic Papers No. 425. Brussels: European Commission, Directorate-General for Economic and Financial Affairs. 
Jimborean, R., \& Kelber, A. (2017). Foreign Direct Investment drivers and growth in Central and Eastern Europe in the aftermath of the 2007 global financial crisis. Comparative Economic Studies, 59(1), 23-54. doi: https://doi.org/10.1057/ s41294-016-0018-9

Keren, M., \& Ofer, G. (2002). The role of FDI in trade and financial services in transition: What distinguishes transition economies from developing economies? Comparative Economic Studies, 44(1), 15-45. doi: https://doi.org/10.1057/ ces. 2002.3

Kersan-Škabić, I., \& Tijanić, L. (2014). The influence of Foreign Direct Investments on regional development in Croatia. Croatian Economic Survey, 16(2), 59-90. doi: https://doi.org/10.15179/ces.16.2.3

Koepke, R. (2015). What drives capital flows to emerging markets? A survey of the empirical literature. MPRA Working Paper No. 62770.

Kovtun, D., Meyer Cirkel, A., Murgasova, Z., Smith, D., \& Tambunlertchai, S. (2014). Boosting job growth in the Western Balkans. IMF Working Paper No. 14/16. Washington, DC: International Monetary Fund.

Lane, P. R., \& Milesi-Ferretti, G. M. (2006). Capital flows to Central and Eastern Europe. IMF Working Paper No. 06/188. Washington, DC: International Monetary Fund.

Lankes, H. P., Stern, N., Blumenthal, W. M., \& Weigl, J. (1999). Capital flows to Eastern Europe. In: M. Feldstein (Ed.), International capital flows (pp. 57-110). Chicago, IL: Chicago University Press.

Lipschitz, L., Lane, T., \& Mourmouras, A. (2002). Capital flows to transition economies: Master or servant? IMF Working Paper No. 02/11. Washington, DC: International Monetary Fund.

Magud, N. E., Reinhart, C. M., \& Vesperoni, E. (2014). Capital inflows, exchange rate flexibility, and credit booms. Review of Development Economics, 18(3), 415-430. doi: https://doi.org/10.1111/rode.12093 
Meyer, K. E. (1995). Direct Foreign Investment in Eastern Europe: The role of labor costs. Comparative Economic Studies, 37(4), 69-88. doi: https://doi. org/10.1057/ces.1995.42

Mitra, P. (2011). Capital flows to EU New Member States: Does sector destination matter? IMF Working Paper No. 11/67. Washington, DC: International Monetary Fund.

Murgasova, Z., Ilahi, N., Miniane, J., Scott, A., Vladkova-Hollar, I., \& the IMF staff team. (2015). The Western Balkans: 15 years of economic transition. Regional economic issues special report. Wshington, DC: International Monetary Fund.

Nier, E., Sedik, T. S., \& Mondino, T. (2014). Gross private capital flows to emerging markets: Can the global financial cycle be tamed? IMF Working Paper No.14/196. Washington, DC: International Monetary Fund.

The World Bank. World Development Indicators dataset. Retrieved from: https:// datacatalog.worldbank.org/dataset/world-development-indicators.

The World Bank. World Governance Indicators dataset. Retrieved from: https:// datacatalog.worldbank.org/dataset/worldwide-governance-indicators.

von Hagen, J., \& Siedschlag, I. (2010). Managing capital flows: Experiences from Central and Eastern Europe. In M. Kawai and M. B. Lamberte (Eds.), Managing capital flows: The search for a framework (pp. 192-213). Cheltenham and Northampton, MA: Edward Elgar Publishing. doi: https://doi.org/10.4337/978 1849806879.00016 